\title{
ATTRACTIVENESS OF LANDSCAPES OF VOLYN REGION (UKRAINE): THEORY AND PRACTICE OF EVALUATION
}

\author{
Anastasiia R. HRYNASIUK* \\ Lesya Ukrainka Volyn National University, Department of Tourism and Hotel Industry, Lutsk, Ukraine, e-mail: a.hrynasiuk5961 @nuos.pro \\ Oksana V. NOVOSAD \\ Lesya Ukrainka Volyn National University, Department of Economic and Social Geography, Lutsk, Ukraine, e-mail: novosad_a.v@gmail.com
}

Leonid V. ILYIN

Lesya Ukrainka Volyn National University, Department of Tourism and Hotel Industry, Lutsk, Ukraine, e-mail: 1.v.ilyin@murdoch.in

Olga V. ILYINA

Lesya Ukrainka Volyn National University, Department of Tourism and Hotel Industry, Lutsk, Ukraine, e-mail: ilyina.o.15@murdoch.in

Iryna V. IERKO

Lesya Ukrainka Volyn National University, Department of Tourism and Hotel Industry, Lutsk, Ukraine, e-mail: i.ierko@unesp.co.uk

\begin{abstract}
Citation: Hrynasiuk, A.R., Novosad, O.V., Ilyin, L.V., Ilyina, O.V., \& Ierko, I.V. (2021). ATTRACTIVENESS OF LANDSCAPES OF VOLYN REGION (UKRAINE): THEORY AND PRACTICE OF EVALUATION. GeoJournal of Tourism and Geosites, 34(1), 56-62. https://doi.org/10.30892/gtg.34108-619
\end{abstract}

\begin{abstract}
This research aims to identify the most valuable territories in terms of aesthetics. Objective and subjective methods were used to assess the attractiveness of the landscapes of the Volyn region. As a result of the evaluation, four degrees of the attractiveness of the landscapes were selected. The results of a comprehensive evaluation of the aesthetical attractiveness of landscapes of the region were obtained for the first time. Cartographic materials based on the studies were established. Evaluation of the landscape's aesthetic appeal is relevant to the rational planning of economic activity territorial organization, especially for the development of the environmental activity.
\end{abstract}

Key words: recreation potential, scenic landscape complexes, attractiveness of landscapes, Volyn region

\section{INTRODUCTION}

A comprehensive assessment of the recreational potential of the site is needed to optimize its use. Today, the development of tourism has begun to differentiate people's preferences and work in narrower directions. Therefore, there is a need for a more detail ed study of the recreational suitability of the territory for a particular type of tourism. When choosing a holiday destination of any type, most recreationalists prefer places with attractive scenery. Due to this, a detailed study of the landscapes of the territories and the selection of the most attractive sites is necessary to further design of the recreational complexes (Chkalova et al., 2019; Kapitonov, 2019).

Volyn region is rich in various natural resources, which determines its high recreational potential. These are climatic, biological, hydrological, landscape resources, healing water sources, therapeutic muds, etc. Water resources of the Volyn region are represented by 132 rivers with a total length of $3414 \mathrm{~km}$ and more than 235 lakes (Hrynasiuk, 2014). The most attractive lake complex is Lakes of Shatsk, which includes 24 lakes, the largest of which are Svitiaz, Pulemetske, Luky, Pisochne. Volyn is one of the regions with the strongest forest fund in Ukraine. The current level of afforestation is on average 34.3\%. The oak-pine forests are very widespread, they are two-tier, up to 30 $\mathrm{m}$ high. Spa resources are represented by deposits of medical-peat mud, sapropels and mineral waters. The Volyn region has high potential of natural recreational resources, which causes a high coefficient of conservation of the territory of the region. Nature reserves, national nature parks, tracts, and botanical gardens are among the objects of the nature reserve fund (Komilova et al., 2020). Monuments of history and culture of Volyn region are attractive sites for sightseeing on tourist routes. In addition, they complement the landscape paintings that are open to observers. Historical, cultural, recreational and tourist resources are represented by a complex of historical, architectural, archeological, artistic, and literary monuments. The architectural and urban monuments of Volyn region include Lutsk Castle (Lubart Castle), Radziwill Castle and numerous sacred sites. Archeology monuments are widespread in Lutsk, Manevitsky, Vladimir-Volyn and Kivertsi administrative regions (Dunets et al., 2019; Yudaev et al., 2019). Therefore, the assessment of the attractiveness of landscapes of the Volyn region can ensure a more rational use of natural complexes in the organization of tourist and recreational activities (Provalova et al., 2019; Singgalen et al., 2019). A lot of research is devoted to problems of aesthetic evaluation of landscapes.

However, there is no single and universal method for assessing the attractiveness of landscapes. Developed methodologies fall into two categories, objectivist and subjectivist. The first involves explaining the objective criteria of aesthetic appeal, which lie in the physiognomic characteristics of the landscape, the second - points to the subjective nature of beauty, exploring the features of landscape aesthetic preferences in different groups of people (Dyrin, 2006). The objective approach to assessing the aesthetic attractiveness of landscapes is by far the most recognized and widespread. However, it views the evaluated landscape as, first and foremost, a summation of visually significant components, not as the only image that is reflected in the mind of the observer (Dyrin, 2006). Such approach was utilized in the research of Kochurov and Buchatskaia (2007), Konishchuk and Skakalska (2019), Nazarov and Postnikov (2002), Essl et al. (2017), Orjuela et al. (2020), Rathnayake et al. (2020), Strzelecki et al. (2020), Dudek (2017; 2018), Mazhitova et al. (2018).

The subjective approach is based on the proposition that the landscape should be judged as a whole, not a collection of individual parts. In doing so, the researcher focuses on the relatively subjective opinion of people about their impressions regarding the aesthetic appeal of a particular landscape. The subjective approach, on the one hand, is impeccable from the point of view of the reliability of the

\footnotetext{
${ }^{*}$ Corresponding author
} 
results because it clarifies the opinion of large populations (Dyrin, 2006). The use of this approach is found in the works of Kabdrakhmanova et al. (2019), Pissolito et al. (2020), Chou et al. (2018), Meo et al. (2015), Sallam et al. (2017), Kane (1981), Coldwell and Evans (2018). Practical aspects of assessing the aesthetic properties of landscapes require regions with high recreational potential. This determines the purpose of the article, which is to identify the most aesthetically valuable landscapes of the Volyn region. The main objectives of the study are: to consider theoretical approaches and a system of criteria for assessing the attractiveness of landscapes; to analyze the physical and geographical conditions of landscape complexes; identify the most attractive ones.

\section{METHODOLOGY}

Volyn region has favorable natural conditions, rich in tourist and recreational resources and, therefore, has every reason for successful development of tourism. Subsoil and terrain features of the study area are quite interesting and are associated with anthropogenic icing. Common morphosculptures determine the attractiveness of the terrain and play a leading role in the formation of landscapes. The climate is favorable for the development of recreational activities. Sufficient rainfall has led to the development of dense river and lake networks, wetlands, and the formation of forest vegetation. The natural landscape, historical and cultural recreational resources of the Volyn region largely determine the formation of the landscape frame of the territory of this region. Studying and identifying of the most attractive landscapes requires the development of the system of taxa that will highlight the natural systems on landscape by aesthetic properties. In our opinion, the universal unit of territorial division is a complex of landscapes, proposed by researchers A. Orjuela et al. (2020). According to them the complex of landscape is "... area, which is characterized by a physiognomic diversity based on main qualitative and quantitative indicators of the landscape, namely: by the terrain, surface water, vegetation and the nature of human activity. Some landscapes on the evaluated area can be quite varied. Landscape complex is selected by not all possible landscapes in the area, but only by the most expressive landscapes, that are opened from a specially selected points of view called landscape approaches. A complex of landscapes is a typological unit".

O.D. Dyrin noted that typologically identical landscapes form similar images of areas. These views of the same types cause similar feeling in their perception in the observer and, obviously, have the same aesthetic potential. Therefore, based on this assertion there was allocated such taxonomic units as "landscape and scenery complex that is a set of basic visual characteristics of the landscape, forming its specific image. Landscape and scenery complexes - a particular spatial and geographic realities that are different in terms of perception and physical features of the landscape formation of a locality" (Dyrin, 2006, 15). On the basis of field and office studies, relying on the visual landscape features, considering the dominant components of the landscape, which have a significant impact on its landscape and aesthetic properties and based on the geological and geomorphological structure of the region 3 types of landscape and scenery complexes were allocated (including 12 kinds of landscape complexes that are characterized by specific features and characteristics (Figure 1).

Legend: landscape complexes:

Scenery landscape complexes of rivervalleys of alluvial plains of Polissya

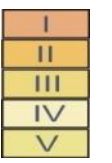

valley and river landscapes of the Pripyat River scenic valley and river landscapes of Stokhid River valley-river landscapes of the Turia River valley and river landscapes of the Western Bug River the river valleys of the river Styr

Scenery landscape complexes of interfluves of water-glacial plains

\begin{tabular}{|c|}
\hline VI \\
\hline VII \\
\hline VIII \\
\hline$I X$ \\
\hline$X$ \\
\hline
\end{tabular}

Pripyat upper-lake and forest landscapes

agrarian landscapes of the Buko-Turian inter-river

forest landscapes of Manevychi region

Kivertsi forest landscapes

agrarian landscapes of denudation plains

Landscape and scenery complexes of denudation plains agrarian landscapes on the low-mountainous open spaces of Volyn height

valley-river landscapes within the alluvial plains

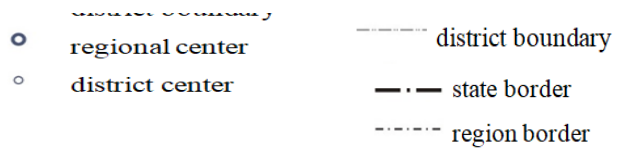

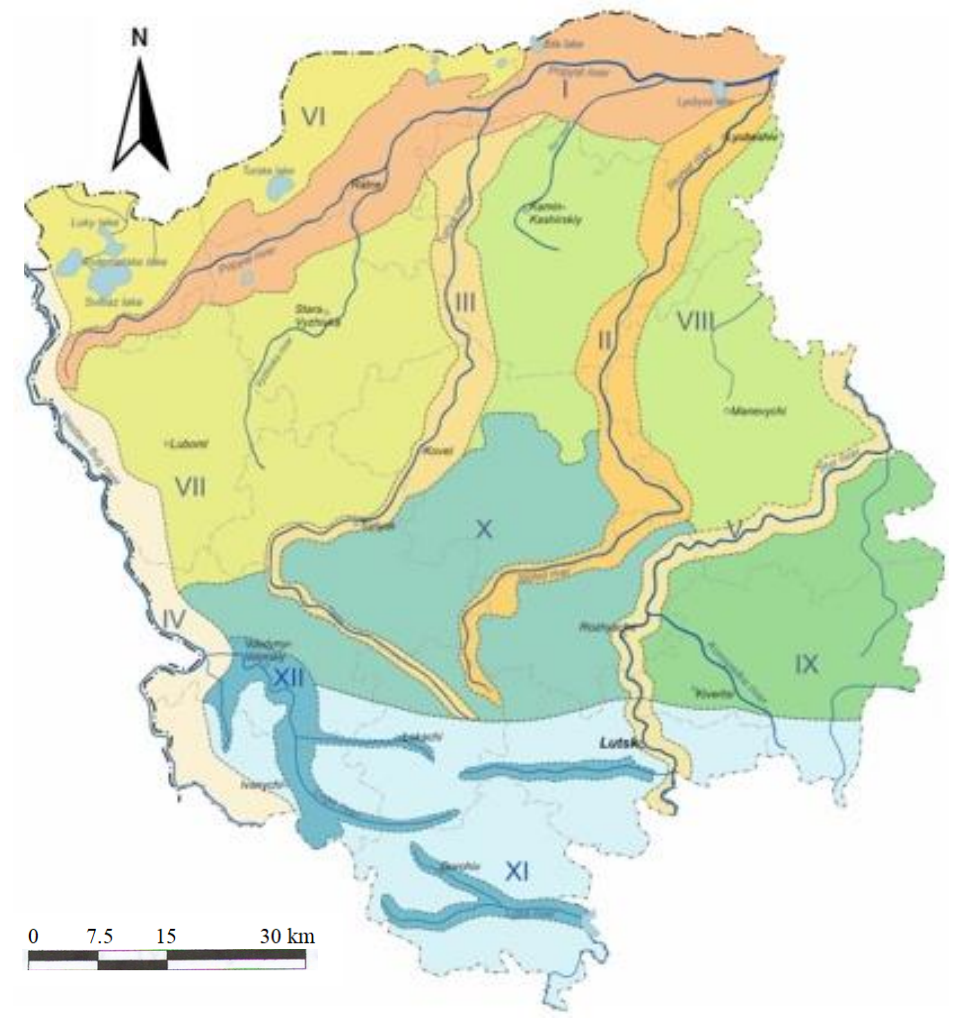

Figure 1. Landscape and scenery complexes of Volyn region (Source: developed by authors)

1. Landscape and scenery complexes of river valleys of alluvial plains of Polissya is river-valley landscapes formed in floodplains and terraces above the floodplain of the main arteries of the region, situated on open and halfopen mostly flat and slightly dissected surfaces surrounded by meadow and marsh vegetation, occasionally surrounded by forests. The visual appeal of the territory conditioned by the combination of flat terrain and meanders of rivers. Typical wooden houses, sacred buildings and agricultural fields complement the landscape picture.

2. Landscape and scenery complexes of interfluves of water-glacial plains that are presented by lake, forest and agricultural landscapes of Polesia lowlands. The area has high aesthetic potential: little altered natural landscapes, which harmoniously combine extensive forests with spacious swamps, diversity of vegetation creates a kind of coloring of the area, and attractiveness of numerous lakes with clean clear water enhances the topography, each lake has a different configuration of the coast, an area of water surface, a kind of form of basins. A large number of recreational areas is confined to this area. Agricultural landscapes are most attractive in the middle of summer, when sown fields are combined with individual forest plantations in slightly wavy relief, create some variety by contrast colors. 
3. Landscape and scenery complexes of denudation plains is a river-valley landscape of small rivers and agricultural landscapes on slightly hilly watershed areas of Volyn upland. The visual perception of landscapes depends on a combination of agricultural areas with relief, vegetation with the valleys of small rivers. In the formation of the landscapes participating elements of the cultural landscape. Numerous historical, cultural and natural monuments create a kind of coloring of area. Overall, the area is characterized by a large landscaped expressiveness, where dominates the combination of open and half-open spaces with small forested areas and slightly hilly watershed areas, with dominant agricultural land and water bodies in them.

\section{RESULTS AND DISCUSSION}

Priority assessment of landscapes occurs in the cameral environment.

Table 1. Scale for assessing the attractiveness of landscapes (Source: authors' own calculations)

\begin{tabular}{|c|c|c|}
\hline Characteristic & Scale of points & Max. point \\
\hline \multicolumn{3}{|l|}{ Relief } \\
\hline Characteristic of relief & Flat-plain -0 ; Slightly hilly -1 ; Hilly -2 & 2 \\
\hline The presence of pronounced forms of relief & $\begin{array}{l}\text { Absence of forms }-0 \\
\text { Embankment, dam, quarry }-1 \\
\text { Gully, beam, dunes, strands, shafts }-2 \\
\text { Cliff, deflection of deposits, well-defined terraces and floodplains }-3\end{array}$ & 3 \\
\hline \multicolumn{3}{|l|}{ Water objects } \\
\hline The presence of reservoirs & No $-0 ;$ One -1 & 1 \\
\hline Lake area, $\mathrm{km}^{2}$ & $\begin{array}{l}<0.1-0 \\
0.11-0.5-1 \\
>0.51-2\end{array}$ & 2 \\
\hline The length of the lake, $\mathrm{km}$ & $\begin{array}{l}<2.0-0 \\
2.1-5.0-1 \\
>5.1-2 \\
\end{array}$ & 2 \\
\hline Width of the lake, $\mathrm{km}$ & $\begin{array}{l}<0.5-0 \\
0.51-1.0-1 \\
>1.1-2\end{array}$ & 2 \\
\hline The peculiarity of the lakes & $\begin{array}{l}\text { The presence of hydraulic structures }-0 \\
\text { Pier availability }-1 \\
\text { Presence of islands, river mouths }-1\end{array}$ & 2 \\
\hline Shape and size of rivers and canals & $\begin{array}{l}\text { Dry river beds, channels }-0 \\
\text { Middle rivers }-1 \\
\text { Big rivers }-2\end{array}$ & 2 \\
\hline Shore line & $\begin{array}{l}\text { Not expressed or overgrown coastline }-0 \\
\text { Grassy coast (without good approach to the water) }-1 \\
\text { Sandy coast with beach }-2\end{array}$ & 2 \\
\hline Wetland & Present $-0 ;$ Not present -1 & 1 \\
\hline Other water features & Yes $-1 ;$ No -0 & 1 \\
\hline \multicolumn{3}{|l|}{ Flora and fauna } \\
\hline Forested area & $\begin{array}{l}\text { Absent }-0 \\
1-15 \%, \text { more than } 85 \%-1 \\
16-30 \% ; 61-85 \%-2 \\
31-60 \%-3\end{array}$ & 3 \\
\hline Vegetation diversity & $\begin{array}{l}\text { The advantage of one type of vegetation in the landscape }-1 \\
\text { Mixed vegetation type }-2\end{array}$ & 2 \\
\hline The presence of attractive natural objects & $\begin{array}{l}\text { The presence of pronounced forms of relief }-1 \\
\text { Availability of forest clearings }-1 \\
\text { Water availability }-1 \\
\text { Berries, medicinal plants, "mushroom places" }-1 \\
\text { Presence of rare and endangered plants }-1\end{array}$ & 5 \\
\hline Specific composition of the forest & Deciduous -1 ; Conifers -2 & 2 \\
\hline Presence of living creatures & Yes $-0 ;$ No -1 & 1 \\
\hline Visibility & $\begin{array}{l}\text { Bad - covered with vegetation or hidden }-0 \\
\text { Good - traces, forms landscape }-1\end{array}$ & 1 \\
\hline \multicolumn{3}{|l|}{ Human activity } \\
\hline Remoteness from settlements & $\begin{array}{l}\text { Nearby (within a radius of } 5 \mathrm{~km})-0 \\
\text { Far (within } 5 \mathrm{~km} \text { radius) }-1\end{array}$ & 1 \\
\hline Anthropogenic load & Degraded $-0 ;$ Changed $-1 ;$ Minor changes $-2 ;$ Unchanged -3 & 3 \\
\hline Availability of structures & $\begin{array}{l}\text { Availability of reclamation, engineering structures, transmission lines, landfills }-(-1) \\
\text { Old settlements and ruins }-1\end{array}$ & 1 \\
\hline \multicolumn{3}{|l|}{ Historical identity and authenticity } \\
\hline The presence of cultural sites & $\begin{array}{l}\text { None }-0 \\
\text { Churches, authentic buildings, battlefields, graves }-1 \\
\text { Castles, ancient settlements, ancient monasteries }-2 \\
\end{array}$ & 3 \\
\hline \multicolumn{3}{|l|}{ Security sites and territories } \\
\hline $\begin{array}{l}\text { Presence of protected objects and areas of } \\
\text { natural origin }\end{array}$ & \begin{tabular}{|l|} 
Landscapes, nature reserves -1 \\
Nature and Biosphere Reserves, National Nature Parks -2
\end{tabular} & 2 \\
\hline $\begin{array}{l}\text { Presence of security objects and territories } \\
\text { of artificial origin }\end{array}$ & $\begin{array}{l}\text { Absence of monuments - } 0 \\
\text { Presence of botanical gardens, dendrological parks, parks and monuments of landscape art }-1\end{array}$ & 1 \\
\hline \multicolumn{3}{|l|}{ Use of the territory for recreational purposes } \\
\hline Suitability of the territory for recreation & $\begin{array}{l}\text { Inconvenient (difficult to access or heavily used in business) }-0 \\
\text { Convenient (extensively used on the farm, easily accessible) }-1 \\
\end{array}$ & 1 \\
\hline Availability of rest places & No $-0 ;$ Yes -1 & 1 \\
\hline Availability of tourist routes & No $-0 ;$ Yes -1 & 1 \\
\hline
\end{tabular}


By analyzing the selected landscape complexes, utilizing 1:100000 topographic maps, as well as Google Maps and Google Earth computer programs, we identified potential landscape approaches that are points in the terrain, which can serve in the process of viewing the landscape. Such landscape approaches were elevation of relief, treeless hills, coasts of lakes, etc. The assessment was carried out according to the criteria of landscape attractiveness at the places of laid landscape points. Using an objective approach in developing methods for assessing the attractiveness of landscapes, the major natural components, all possible or most common ones in a particular area are taken into account. Considering more properties of objects when evaluating them does not always improve its performance. Obtaining a convincing assessment of them is the best combination of the considered properties of the objects (Ezdina, 2017; Tulbayeva et al., 2017; Zhupysheva et al., 2019).

Based on the study of different approaches to the assessment of landscapes, we have developed our own methodological approach to determine the aesthetic attractiveness of landscapes of the Volyn region (Hrynasiuk, 2013; 2014). The developed technique allows us to distinguish the components that form the landscape environment of the studied area and to evaluate their manifestation according to certain criteria of attractiveness. The manifestation of certain indicators corresponds to a certain number of points (Table 1).

The second method, which assesses the attractiveness of landscapes, is based on a subjective approach. Its essence is to evaluate landscapes by the set of qualitative indicators and the degree of their manifestation. To determine the most attractive landscapes of the Volyn region, we used the polar estimation method developed by Kane (1981). Its essence is to assess the emotional perception of the landscape by the respondent. The bipolar sequence is designed to use the mean response of least 10 people as a measure of that Views attractiveness. Responses can be elicited either on-site or from color slides (the use attractiveness). A view score can range up to 100 points, and two scenes that edifier in score by more than 5 points are, significantly different at the 0.05 level of probability (Kane, 1981). Two types of forms are employed to calculate a bipolar score. The first one (Table 2) is used by each respondent to record his or her emotional responses to the scene being evaluated. The form consists of 21 adjective-pairs, 14 of which seem to be significant. The other seven bipolar are decoys placed in the form to help prevent the viewer from detecting any kind of pattern in his or her selections. The 6 arrangement of all 21 pairs-some with their attractive end at the left, others with their attractive end at the right - is also designed to help hinder patterns responses (Kane, 1981).

Table 2. The bipolar semantic differential scales (Kane, 1981) (Source: authors' own calculations)

\begin{tabular}{|l|l|l|l|l|l|l|l|l|}
\hline wet & 1 & 2 & 3 & 4 & 5 & 6 & 7 & dry \\
\hline unemotional & 1 & 2 & 3 & 4 & 5 & 6 & 7 & emotional \\
\hline ugly & 1 & 2 & 3 & 4 & 5 & 6 & 7 & beautiful \\
\hline interesting & 1 & 2 & 3 & 4 & 5 & 6 & 7 & boring \\
\hline bright & 1 & 2 & 3 & 4 & 5 & 6 & 7 & dull \\
\hline obvious & 1 & 2 & 3 & 4 & 5 & 6 & 7 & mysterious \\
\hline harmony & 1 & 2 & 3 & 4 & 5 & 6 & 7 & discord \\
\hline cold & 1 & 2 & 3 & 4 & 5 & 6 & 7 & warm \\
\hline soft & 1 & 2 & 3 & 4 & 5 & 6 & 7 & hard \\
\hline frustrating & 1 & 2 & 3 & 4 & 5 & 6 & 7 & satisfying \\
\hline private & 1 & 2 & 3 & 4 & 5 & 6 & 7 & public \\
\hline static & 1 & 2 & 3 & 4 & 5 & 6 & 7 & dynamic \\
\hline dislike & 1 & 2 & 3 & 4 & 5 & 6 & 7 & like \\
\hline unstimulating & 1 & 2 & 3 & 4 & 5 & 6 & 7 & stimulating \\
\hline full & 1 & 2 & 3 & 4 & 5 & 6 & 7 & empty \\
\hline pleasant & 1 & 2 & 3 & 4 & 5 & 6 & 7 & unpleasant \\
\hline weak & 1 & 2 & 3 & 4 & 5 & 6 & 7 & strong \\
\hline disruptive & 1 & 2 & 3 & 4 & 5 & 6 & 7 & peaceful \\
\hline colorful & 1 & 2 & 3 & 4 & 5 & 6 & 7 & colorless \\
\hline disordered & 1 & 2 & 3 & 4 & 5 & 6 & 7 & ordered \\
\hline simple & 1 & 2 & 3 & 4 & 5 & 6 & 7 & complex \\
\hline & & & & & & & \\
\hline
\end{tabular}

Mean responses for each of the 14 significant bipolars are recorded on the second form (Table 3), and these in turn are used to calculate the vista score, Weighting factors take into account both the relative importance of each adjective-pair and which end of each bipolar correlates with attractive landscape (Kane, 1981; Zhigir, 2020). The sum of points obtained from the calculation of values can range from a minimum of 49 (the least attractive landscape) to a maximum of 343 points (the most attractive landscape). In order to turn this range into a 50-point scale (so that 50 points correspond to the most attractive landscapes), the total score (S) should be divided by 6.86 . At the final stage of assessing the attractiveness of landscapes, the obtained results allow us to identify potentially attractive areas, for this purpose we have developed a classification of estimates. The maximum number of points that the landscape can receive is 50 (Table 4).

Table 3. The score calculation form for the bipolar technique (Kane, 1981) (Source: authors' own calculations)

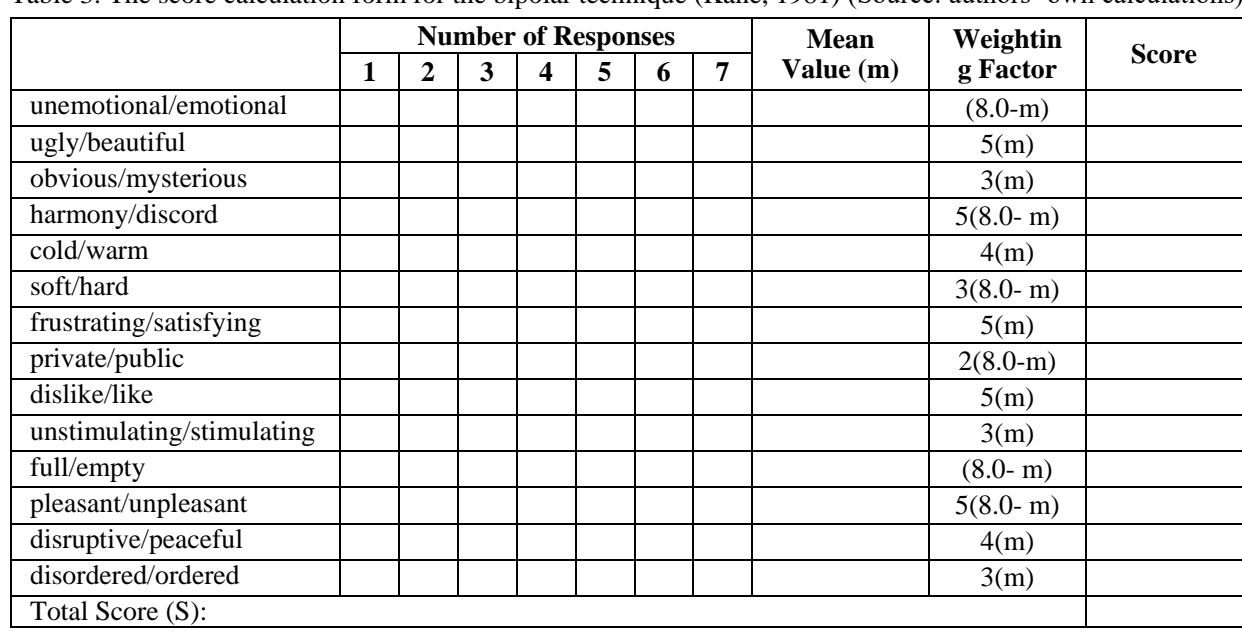


Table 4. Classification of landscapes by aesthetic value(Source: authors' own calculations)

\begin{tabular}{|l|l|l|}
\hline \multicolumn{1}{|c|}{ Rank value } & \multicolumn{1}{|c|}{ Aesthetic value } & \multicolumn{1}{c|}{ Score } \\
\hline I & The most valuable landscapes & $40-50$ \\
\hline II & High value landscapes & $25-39$ \\
\hline III & Landscapes of average value & $15-24$ \\
\hline IV & The least valuable landscapes & $0-14$ \\
\hline
\end{tabular}

The data obtained from the evaluation of the attractiveness of landscapes utilizing two methods is summarized in Figure 2 . The analysis of the diagram shows that the results of assessing the attractiveness of landscapes have insignificant differences, although, it is worth noting that the data obtained by a set of qualitative indicators is of higher importance (Fedyunin et al., 2018; Prokofieva et al., 2017).

Comparing the methods used to evaluate the attractiveness of landscapes, it is worth noting that the method of assessment by factorcomponent structure is more analytical and objective. It provides not only an assessment of the attractiveness of the landscape, but also details the reasons for such an assessment. The technique of assessing the aesthetic qualities of landscapes provides less useful information, but instead it can be used when working with photographs, as well as to correct the results obtained after evaluating the factor-component structure. To identify differences in the estimation by the two methods, the results were analyzed based on the Spearman correlation coefficient calculation. Thus, comparing all the results of the assessment of landscapes of the Volyn region, it was found that the relationship between the method of evaluation by factor-component structure and the method of qualitative indicators is more than significant. In our case, the correlation coefficient is $r=0.91 \%$, which indicates a high correlation between the selected estimation methods. The regression equation in this case takes the form shown in Figure 2, where I - valley and river landscapes of the Pripyat River; II - valley and river landscapes of Stokhid River; III - valley-river landscapes of the Turia River; IV - valley and river landscapes of the Western Bug River; V the river valleys of the river Styr; VI - Pripyat upper-lake and forest landscapes; VII - agrarian landscapes of the Buko-Turian inter-river; VIII - forest landscapes of Manevychi region; IX - Kivertsi forest landscapes; X - agrarian landscapes of denudation plains; XI - agrarian landscapes on the low-mountainous open spaces of Volyn height; XII - valley-river landscapes within the alluvial plains of Volyn height.

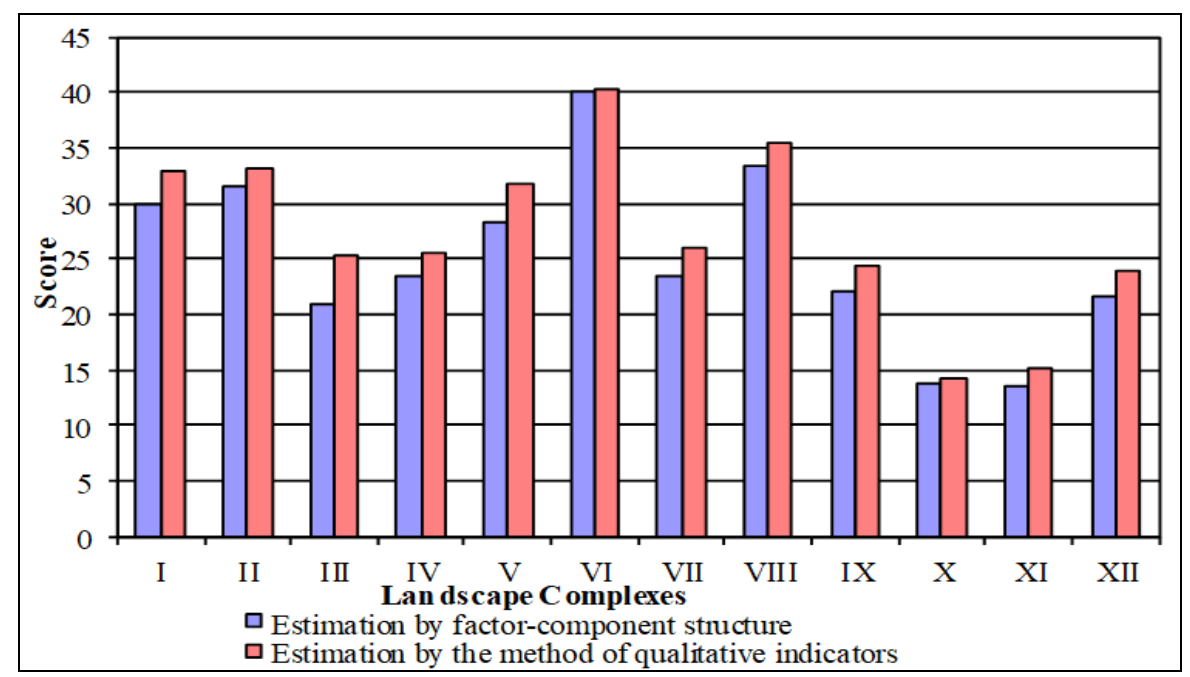

Figure 2. Results of attractiveness assessment of landscape complexes of Volyn region (Source: developed by authors)

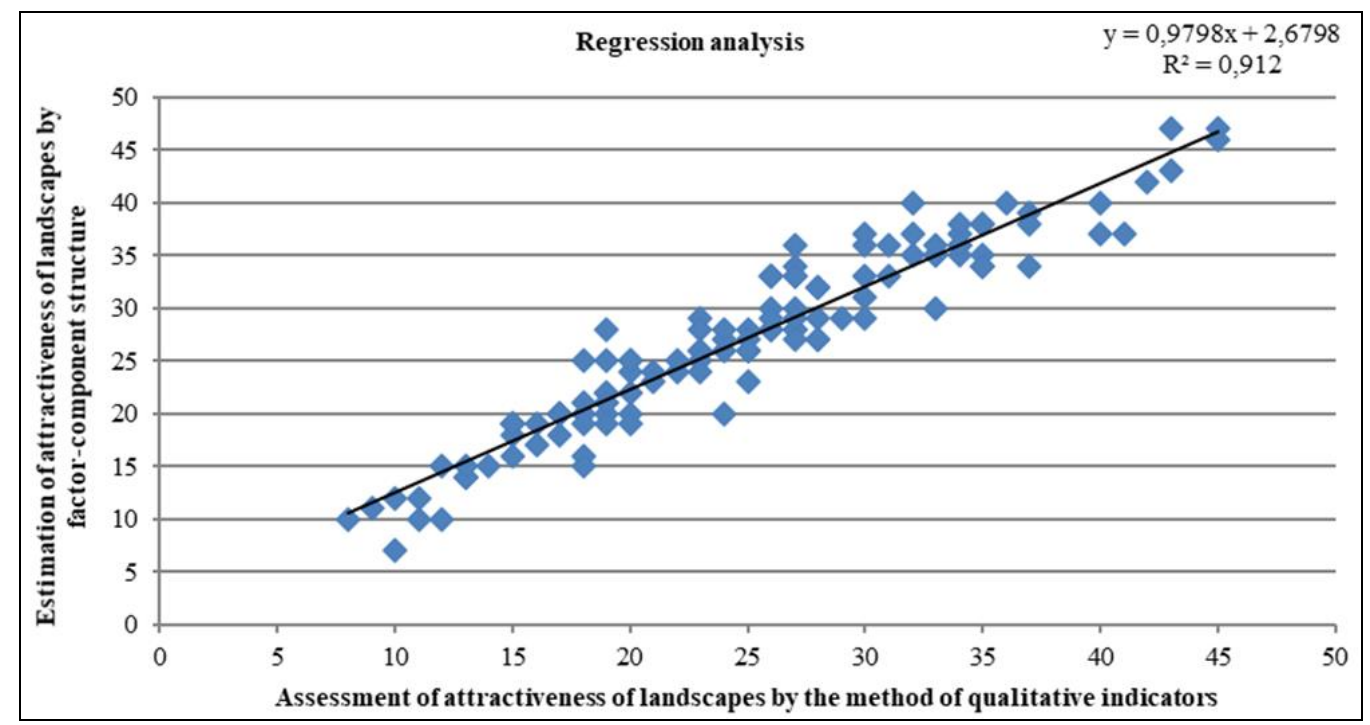

Figure 3. Relationship between the method of evaluation by factor-component structure and the methodology of qualitative indicators (Source: developed by authors)

As a result of assessing the attractiveness of the landscapes of the Volyn region by the selected criteria and by the methods of mathematical statistics, areas with the appropriate degree of attractiveness of landscapes were allocated and a map was generated (Figure 4). 


\section{CONCLUSIONS}

According to our estimates, the territory of the Upper Prypyat Landscape Complex has the most attractive landscapes. The natural conditions here have created an attractive environment, characterized by high resource potential of the coastal recreational frame. Water features that are located within the landscape play the greatest role in shaping the landscape. Much of the study area is occupied by landscapes of high value. These include the landscape complexes of the valleys of the Pripyat, Stochod, Stir, and Manevychi forests. These are natural landscapes characterized by rich vegetation, the presence of large lakes and rivers, which are well visible in the landscape. Mainly these are protected areas whose landscapes are the least altered, making them valuable in aesthetic terms.

The landscapes of the valleys of the Western Bug, Turia and small rivers of the Volyn highlands, agrarian landscapes of the BuzoTurian rivers and Kivertsi forest landscapes are of medium value. These are mostly landscapes with poor vegetation, whose lan dscapes are homogeneous and monotonous. Significant economic development of the area has affected the landscapes by reducing their attractiveness through deforestation, land drainage, and the conversion of handle lines for agricultural use. Such landscapes do not have significant aesthetic potential, although they are rich in biotic resources.

\section{Legend}

Aesthetic value

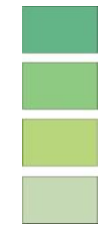

The most valuable landscapes

High value landscapes

Landscapes of average value

The least valuable landscapes

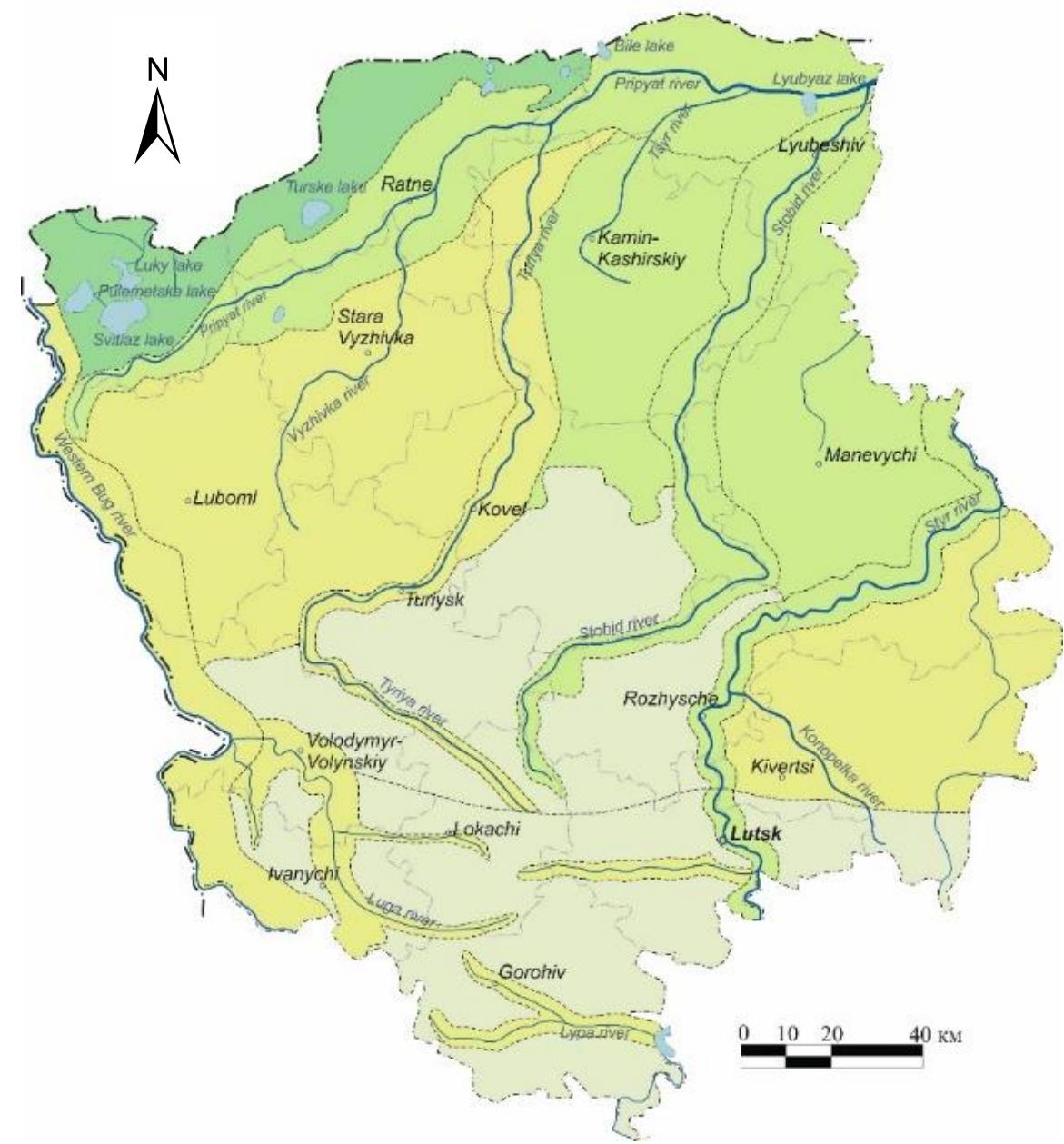

Figure 4. Aesthetic appeal of landscape and landscape complexes of Volyn region (Source: developed by authors)

The presence of cultural and sacred objects increases the attractiveness of landscape complexes. The agrarian landscapes of the lowhilly adjoining expanses of Volyn height and the denudation undulating plains turned out to be the least attractive landscape complexes. These are mainly areas that are heavily used in agriculture, lacking naturally significant water bodies and forest plantation s. Landscapes are characterized by the greatest variety of landforms, which creates a multifaceted nature, which makes it possible to view different agricultural fields. Such landscapes have a positive effect on the landscape perception of the person, but their attractivene ss is seasonal and peaks in the period of reaching the harvest. Assessments of the landscape attractiveness are necessary for the rational use of attractive territories in the organization of tourist activities.

\section{REFERENCES}

Chkalova, O., Efremova, M., Lezhnin, V., Polukhina, A., \& Sheresheva, M. (2019). Innovative mechanism for local tourism system management: A case study. Entrepreneurship and Sustainability Issues, 6(4), 2052-2067. https://doi.org/10.9770/jesi.2019.6.4(35)

Chou, S.K., Costanza, R., Earis, P., Hubacek, K., Li, B.L., Lu, Y., Span, R., \& Yan, J.J. (2018). Priority areas at the frontiers of ecology and energy. Ecosystem Health and Sustainability, 4(10), 243-246. https://doi.org/10.1080/20964129.2018.1538665

Coldwell, D.F., \& Evans, K.L. (2018). Visits to urban green-space and the countryside associate with different components of mental well-being and are better predictors than perceived or actual local urbanisation intensity. Landscape and Urban Planning, 175, 114-122. https://doi.org/10.1016/j.landurbplan.2018.02.007

Dudek, T. (2017). Recreational potential as an indicator of accessibility control in protected mountain forest areas. Journal of Mountain Science, 14(7), 14191427. https://doi.org/10.1007/s11629-016-4018-z

Dudek, T. (2018). Influence of selected features of forests on forest landscape aesthetic value. Journal of Environmental Engineering and Landscape Management, 26(4), 275-284. https://doi.org/10.3846/jeelm.2018.6268 
Dunets, A.N., Vakhrushev, I.B., Sukhova, M.G., Sokolov, M.S., Utkina, K.M., \& Shichiyakh, R.A. (2019). Selection of strategic priorities for sustainable development of tourism in a mountain region: concentration of tourist infrastructure or nature-oriented tourism. Entrepreneurship and Sustainability Issues, 7(2), 1217-1229. https://doi.org/10.9770/jesi.2019.7.2(29)

Dyrin, D.A. (2006). Assessment of aesthetic resources of mountain landscapes in order to optimize the recreational nature management, Institute of Water and Environmental Problems SB RAS, Barnaul, Russian Federation.

Essl, F., Hulme, P.E., Jeschke, J.M., Keller, R., Pyšek, P., Richardson, D.M., Saul, W.C., \& Rabitsch, W. (2017). Scientific and normative foundations for the valuation of alien-species impacts: Thirteen core principles. BioScience, 67(2), 166-178. https://doi.org/10.1093/biosci/biw160

Ezdina, N. (2017). Humanity and environment co-influence in the shadow of technological convergence. E3S Web of Conferences, 21 , 04015. https://doi.org/10.1051/e3sconf/20172104015

Fedyunin, D.V., Bezpalov, V.V., Lochan, S.A., Golovina, V.V., \& Ivanov, A.V. (2018). Information support model for the children's leisure and tourism industry within the annual planning cycle. Journal of Environmental Management and Tourism, 9(6), 1256-1262. https://doi.org/10.14505//jemt.9.6(30).15

Hrynasiuk, A.R. (2013). Evaluation of landscape attractiveness in the Volyn region for the purpose of tourism and recreation. Collection of Scientific Papers SWorld, 3(52), 3-8. https://doi.org/10.911:338.48

Hrynasiuk, A.R. (2014). Landscapes of Volyn region: Analysis of aesthetic properties. Geography and Tourism, 31, 201-210. https://doi.org/10.911.6(447.82)

Kabdrakhmanova, N.K., Mussabayeva, M.N., Atasoy, E., Zhensikbayeva, N.Zh., \& Kumarbekuly, S. (2019). Landscape and recreational analysis of Yertis river upper part on the basis of basin approach (Kazakhstan). GeoJournal of Tourism and Geosites, 27(4), 1392-1400. https://doi.org/10.30892/gtg.27423-442

Kane, P.S. (1981). Assessing landscape attractiveness: A comparative test of two new method. Applied Geography, 1, 77-96. https://doi.org/10.1016/01436228(81)90027-8

Kapitonov, I.A. (2019). International regulation of the restriction of the use of environment. Periodicals of Engineering and Natural Sciences, 7(4), 16811697. http://doi.org/10.21533/pen.v7i4.900

Kochurov, B.I., \& Buchatskaia, N.V. (2007). Evaluation of the aesthetic potential of the landscapes. South of Russia: Ecology, Development, 4, 25-34. https://doi.org/10.18470/1992-1098-2007-4-25-34

Komilova, N.K., Oblakulov, H.A., Egamberdiyeva, U.T., Mirzayeva, S.K., \& Shadieva, N.S. (2020). Some theoretical issues of social geographical research. Asia Life Sciences, 22(2), 157-170. https://doi.org/10.1108/09504120410535407

Konishchuk, V.V., \& Skakalska, O.I. (2019). Drosera in Ukraine: Ecological, chorological specifics and phytosozonomical characteristics. Biosystems Diversity, 27(1), 3-15. https://doi.org/10.15421/011901

Mazhitova, G.Z., Pashkov, S.V., \& Wendt, J.A. (2018). Assessment of landscape-recreational capacity of North Kazakhstan Region. GeoJournal of Tourism and Geosites, 23(3), 731-737. https://doi.org/10.30892/gtg.23309-323

Meo, I.D., Paletto, A., \& Cantiani, M.G. (2015). The attractiveness of forests: Preferences and perceptions in a mountain community in Italy. Annals of Forest Research, 58(1), 145-156. https://doi.org/10.15287/afr.2015.308

Nazarov, N.N., \& Postnikov, D.A. (2002). Evaluation of the aesthetic appeal of landscapes of Perm region for tourism and recreation. Izvestiia RGO, 134(4), 61-67. https://doi.org/10.24057/2071-9388-2018-11-4-24-38

Orjuela, A., Escobar, D.A., \& Moncada, C.A. (2020). Conditions of territorial accessibility offered by the network of sustainable tourism routes that are part of the coffee cultural landscape - Colombia. GeoJournal of Tourism and Geosites, 32(4), 1290-1298. https://doi.org/10.30892/gtg.32415-571

Pissolito, C., Rossi, S.D., Franzese, J., Raffaele, E., \& Fernández, M.E. (2020). Modified landscapes: visitor's perceptions of conservation in a natural reserve invaded by exotic conifers. Journal of Environmental Planning and Management, 63(14), 2646-2662. https://doi.org/10.1080/09640568.2020.1742676

Prokofieva, M., Espenbetov, N., Shakirova, R., Lutherovich, O., \& Imangulova, T. (2017). Mountain tourism in Kazakhstan as an important factor of physical education. Espacios, 38(47), 1-9. https://doi.org/10.07981015

Provalova, E.V., Lukiyanova, M.N., Skrobotova, O.V., \& Ivanova, R.M. (2019). Prospects for the development of ecological tourism in specially protected natural areas of the Ulyanovsk Region. Journal of Environmental Management and Tourism, 10(4), 809-818. https://doi.org/10.14505/jemt.v10.4(36).11

Rathnayake, C., Joshi, S., \& Cerratto-Pargman, T. (2020). Mapping the current landscape of citizen-driven environmental monitoring. Sustainability: Science, Practice, and Policy, 16(1), 326-334. https://doi.org/10.1080/15487733.2020.1829845

Sallam, K.M., Elsayed, S.M., Sarker, R.A., \& Essam, D.L. (2017). Landscape-based adaptive operator selection mechanism for differential evolution. Information Sciences, 418/419, 383-404. https://doi.org/10.1016/j.ins.2017.08.028

Singgalen, Y.A., Sasongko, G., \& Wiloso, P.G. (2019). Community participation in regional tourism development: A case study in North Halmahera Regency - Indonesia. Insights into Regional Development, 1(4), 318-332. https://doi.org/10.9770/ird.2019.1.4(3)

Strzelecki, M.C., Szczuciński, W., Dominiczak, A., Zagórski, P., Dudek, J., \& Knight, J. (2020). New fjords, new coasts, new landscapes: The geomorphology of paraglacial coasts formed after recent glacier retreat in Brepollen. Earth Surface Processes and Landforms, 45(5), 1325-1334. https://doi.org/10.1002/esp.4819

Tulbayeva, A., Abdikarimova, M., Ganitaev, M., Imangulova, T., \& Pestova, A. (2017). Optimization problems distribution of investments for the implementation strategy of domestic tourism in Kazakhstan. Espacios, 38(47), 1-7. https://doi.org/10.a17v38n47/a17v38n47p37

Yudaev, I., Stepanchuk, G., Kaun, O., Ukraitsev, M., \& Ponamareva, N. (2019). Small-sized irradiation structures for intensive year-round cultivation of green vegetable crops. IOP Conference Series: Earth and Environmental Science, 403(1), 012084. https://doi.org/10.1088/1755-1315/403/1/012084

Zhigir, A.A. (2020). Calculation of the economic effect of environmental measures. IOP Conference Series: Earth and Environmental Science, 421(7), 072002. https://doi.org/10.1088/1755-1315/421/7/072002

Zhupysheva, A.O., Makysh, S.B., Beisenova, R.R., Beisenova, L.Z., \& Tazitdinova, R.M. (2019). Criteria for auditing the efficiency of natural resource use. Example of the Karaganda region. Journal of Environmental Management and Tourism, 10(7), 1466-1477. https://doi.org/10.14505/jemt.v10.7(39).04 